\title{
W POSZUKIWANIU \\ MODELU USTROJOWEGO PROKURATURY (W ŚWIETLE PRAC KOMISJI RADY EUROPY „DEMOKRACJA POPRZEZ PRAWO”)
}

Dwadzieścia pięć lat od rozpoczęcia procesu transformacji w państwach Europy Środkowej i Wschodniej pokazało, że jednym z najtrudniejszych problemów ustrojowych, z jakim przyszło się zmierzyć wszystkim tym państwom, jest kwestia usytuowania ustrojowego prokuratury. Świadczy o tym m.in. fakt, że w ciągu dwudziestu pięciu lat swojej działalności Komisja Rady Europy „Demokracja poprzez Prawo”, tzw. Komisja Wenecka, przygotowała $\mathrm{w}$ tym zakresie kilkadziesiąt opinii prawnych oceniających rozwiązania dotyczące prokuratury wprowadzane w różnych państwach, a także opracowała swój własny raport, zwierający zasadnicze linie przewodnie dotyczące zasad organizacji prokuratury, będący w dużej mierze efektem tych doświadczeń2 ${ }^{2}$

Jednym z głównych wyzwań w tym zakresie, jakie stanęły przed wszystkimi państwami byłego bloku radzieckiego, było ograniczenie niezwykle szerokiej roli prokuratury opartej na zasadzie tzw. nadzoru ogólnego, tj. możliwości wkraczania prokuratora w kompetencje innych organów, także sądów. Państwa aspirujace do członkostwa w Radzie Europy otrzymywały jej rekomendacje o konieczności dostosowania prawa wewnętrznego do prawa Rady Europy. W większości z nich wskazywano na konieczność reformy systemu sądowego i ograniczenia władzy prokuratury.

Wszystkie te państwa zatem poszukiwały rozwiązań, które zrywając z zasadą jedności władzy, pozwalałyby znaleźć najefektywniejszy model usytuowania prokuratury wpisany w system podziału i równowagi władz. Dyskusja ta w dużej mierze toczy się do dzisiaj. Warto tu także dodać, że nie są od niej wolne także „tradycyjne demokracje”, jak np. Francja czy Austria.

Debata, która toczyła się i toczy, na temat miejsca prokuratury w Polsce jest tylko elementem szerszej dyskusji, jaką obserwować można w innych państwach po 1989 r. Dyskusja w Polsce przybierała niejednokrotnie bardzo emo-

\footnotetext{
${ }^{1}$ Komisja Demokracja poprzez Prawo została utworzona w maju 1990 r. Jest ona swoistym ciałem opiniodawczym Rady Europy w kwestiach konstytucyjnych. Komisja jest szczególnie aktywna w państwach byłego bloku radzieckiego, pomagając im w przygotowywaniu nowych konstytucji oraz ustaw dot. m.in. organizacji władz państwowych, sądownictwa, prokuratury, prawa wyborczego, praw mniejszości narodowych.

2 „European Standards as regards the Independence of the Judicial System, part II - the prosecution service” (CDL-AD(2010)040),
} 
cjonalny charakter - posługiwano się w wielu przypadkach bardziej argumentami natury politycznej aniżeli prawnej. Nie ulega wątpliwości, że elementy polityczne, a zwłaszcza możliwość „wykorzystywania” politycznego prokuratury, mają istotne znaczenie dla debaty w kwestii jej ustrojowego usytuowania. Sądzę jednak, że czas obecny, biorąc także pod uwagę wprowadzone w 2009 r. zmiany do ustawy o prokuraturze, pozwala na chłodniejsze dokonanie pewnych ocen, także na tle rozwiązań w innych państwach.

Punktem wyjścia dalszych rozważań jest teza sformułowana w raporcie Komisji Weneckiej o braku w systemie europejskim jednolitego modelu ustrojowego prokuratury. Daje to legislatorom możliwość wyboru różnych wariantów w ramach tzw. standardów europejskich. I to m.in. różni ten organ od sadownictwa, które od czasów Monteskiusza, stanowiąc trzecią władzę, kieruje się określonym systemem zasad i reguł gwarantujących zarówno niezależność sądów, jak i niezawisłość sędziów. Zasady te tworzą spójny i jednolity system, także na poziomie europejskim, stanowiąc punkt odniesienia dla poszczególnych państw. Występować mogą różnice dotyczące pewnych gwarancji organizacyjnych, ale sam model niezależności sądownictwa od pozostałych władz jest podstawą demokratycznego państwa prawa.

Inaczej natomiast ma się sprawa z prokuraturą. Rozwiązania w różnych państwach demokratycznych są rozmaite. W świetle zasad demokratycznego państwa prawa nie można zatem sformułować tezy, że tylko jeden model ustrojowego usytuowania prokuratury, tj. wyłaczenia jej z władzy wykonawczej, jest dopuszczalny. I to zapewne leży u podstaw stale aktualnej dyskusji na temat miejsca ustrojowego prokuratury oraz sposobu jej regulacji prawnej ${ }^{3}$.

Standardy europejskie niewattpliwie dopuszczają kilka możliwości usytuowania prokuratury w stosunku do innych organów państwowych. Europa jest podzielona w tej kwestii na systemy, w których urząd prokuratora jest niezależny od parlamentu i rządu, oraz na takie, w których jest ona podporządkowana jednej lub drugiej z tych władz, korzysta jednak z pewnego zakresu niezależności w swoich działaniach ${ }^{4}$.

W świetle tej tezy należy zatem stwierdzić, że żadnego z powyższych rozwiązań, czy to podporządkowania parlamentowi, czy podporządkowania rządowi, nie można zakwalifikować jako sprzecznego ze standardami demokratycznymi. Stąd też Komisja Europejska konstatuje, że wskazanie jednego dominującego wzorca europejskiego wydaje się w obecnej sytuacji przedwczesne ${ }^{5}$.

${ }^{3}$ Tytułem przykładu można wskazać niektóre wypowiedzi z obszernej w tym zakresie literatury: S. Waltoś, Prokuratura - jej miejsce wśród organów władzy, struktura i funkcje, „Państwo i Prawo" 2002, z. 4; Z. Witkowski, Kilka uwag na temat prawno-ustrojowego usytuowania prokuratury w konstytucjach wybranych państw wspótczesnej Europy, w: W. Czerwiński (red.), Prokuratura (ustawa, regulamin i inne przepisy, stan na 1 stycznia 1997 r.), TNOiK, Toruń 1997; H. Zięba-Załucka, Instytucja prokuratury w Polsce, Warszawa 2003.

${ }^{4}$ Por. Opinię Komisji Weneckiej: (CDL-AD(2010)040),

${ }^{5}$ "As a prevailing concept, it can be seen, that in the current situation the very notion of European harmonisation round a single concept of a prosecutor's office seemed premature" (CDL$\mathrm{AD}(2010) 040)$. 
Konsekwencją tej różnorodności jest także fakt zróżnicowanej regulacji konstytucyjnej problematyki prokuratury w poszczególnych państwach. Analiza przepisów konstytucyjnych poszczególnych państw Rady Europy w tym zakresie pozwala wyróżnić w zasadzie dwie grupy: te, w których konstytucje reguluja podstawowe funkcje prokuratury ${ }^{6}$, oraz takie, których konstytucje nie zawieraja żadnych regulacji dotyczacych prokuratury ${ }^{7}$. Nie jest też kwestią przypadku, że większość państw należących do pierwszej grupy to państwa, które powstały w wyniku rozpadu Związku Radzieckiego, podczas gdy większość konstytucji tzw. tradycyjnych demokracji nie zawiera przepisów dotyczacych prokuratury.

Nie ulega wątpliwości, że w poszukiwaniu rozwiązań w poszczególnych państwach dla usytuowania prokuratury istotna rolę odgrywała także tradycja prawna danego kraju. Ważne było zwłaszcza to, czy państwo dokonujące transformacji ustrojowej mogło sięgnąc do swoich demokratycznych rozwiązań w kwestii prokuratury z okresu sprzed konstytucji socjalistycznej. Szereg bowiem państw, które powstały po rozpadzie ZSRR, takiej możliwości po prostu nie miało. Jedynym wzorcem był system prokuratury radzieckiej, a nie był to wzorzec, który mógł być naśladowany w procesie demokratycznej transformacji, chociażby z tego względu, że wpisany był w inny system podstawowych zasad ustrojowych.

Polska znajdowała się w tym względzie w innej sytuacji. Miała swoją własną tradycję ustrojowa. Poszukujac optymalnych, w ówczesnych warunkach roku 1989, rozwiąań ustrojowych, sięgano zatem do rozwiązań sprzed wejścia w życie Konstytucji z 1952 r., w przypadku zaś prokuratury - do rozwiązań sprzed 1950 r., tj. do okresu przed uchwaleniem ustawy o prokuraturze ${ }^{8}$, wpisanej całkowicie w system jednolitości władzy i wzorującej się na modelu radzieckim z nadzorem ogólnym prokuratury.

W trakcie negocjacji prowadzonych w ramach Okragłego Stołu uzgodniono szereg zmian do obowiązującej wówczas Konstytucji PRL. W świetle przyjętych wówczas zmian uzasadnione było stwierdzenie, że podejmując w kwietniu, a następnie w grudniu 1989 r. reformę konstytucyjnego systemu organów państwowych, zamierzano wprowadzić do niego elementy podziału władz. $\mathrm{W}$ pakiecie zaproponowanych zmian kwietniowych znalazło się m.in. przywrócenie dwuizbowego parlamentu czy też instytucji prezydenta oraz częściowe zmiany dotyczące sądownictwa, m.in. konstytucjonalizacja Krajowej Rady Sądownictwa9. Wprowadzenie poprawek do Konstytucji przejawiających się w stworzeniu dodatkowych gwarancji niezawisłości sędziów mogło służyć jako dowód na rzecz tezy o wprowadzaniu zasady podziału władz do polskiego systemu ustrojowego ${ }^{10}$.

${ }^{6}$ Tak np. konstytucje: Albanii, Armenii, Azerbejdżanu, Białorusi, Bułgarii, Chorwacji, Cypru, Czarnogóry, Gruzji, Hiszpanii, Irlandii, Litwy, Macedonii, Mołdawii, Portugalii, Rumunii, Rosji, Serbii, Słowacji, Słowenii, Ukrainy, Węgier, Włoch.

${ }^{7}$ Np. konstytucje: Austrii, Belgii, Czech, Danii, Estonii, Francji, Grecji, Holandii, Islandii, Luksemburga, Łotwy, Malty, Niemiec, Norwegii, Polski, Szwajcarii, Turcji.

${ }^{8}$ Ustawa z 20 lipca 1950 r. o prokuraturze RP, Dz. U. 1950, Nr 38, poz. 346.

${ }^{9}$ Ustawa z 7 kwietnia 1989 r. o zmianie Konstytucji PRL, Dz. U. 1989, Nr 19, poz. 101.

${ }^{10}$ Por. H. Suchocka, L. Kański, Zmiany konstytucyjnej regulacji sądownictwa i prokuratury dokonane w roku 1989, „Państwo i Prawo” 1991, z. 1, s. 16. 
Nie podjęto wówczas szerzej kwestii prokuratury. Spór na temat usytuowania prokuratury dzielił wyraźnie strony polityczne ${ }^{11}$. Niezbędne zmiany dotyczyły zatem tylko konsekwencji przywrócenia instytucji prezydenta i likwidacji Rady Państwa, która miała określone kompetencje wobec prokuratora generalnego. Kompetencje te przypisane zostały prezydentowi i stąd w art. 65 ust. 1 wprowadzono zmianę regulująca, że Prokuratora Generalnego PRL powołuje i odwołuje Prezydent, oraz w ust. 3, że Prokurator Generalny zdaje sprawę Prezydentowi z działalności prokuratury ${ }^{12}$. Model prokuratury nie został w wyniku tej nowelizacji zmieniony.

W momencie dokonywania zmian w 1989 r. zgoda polityczna dotyczyła pewnych kwestii ustrojowych, zarysowanych w sposób niezwykle ogólny. Ale taki był to moment konstytucyjny. Liczył się wówczas w większym stopniu efekt polityczny aniżeli rzetelna analiza konstytucyjnoprawna. Na nia wówczas nie było czasu. Było to w jakimś sensie w tamtym okresie zrozumiałe. Dokonywano zmian częściowych, z założenia ograniczonych w czasie.

Kolejne zmiany Konstytucji przeprowadzono w grudniu 1989 r. Wówczas już wyraźnie rysowała się konieczność uchwalenia nowej konstytucji, a poprawki do obowiąujacej miały bardzo ograniczony charakter, polegały raczej na usunięciu swoistych „blokad” przeszkadzających wprowadzaniu zmian ustrojowych związanych z transformacją.

W nurt tych zmian wpisywały się propozycje dotyczace usytuowania prokuratury. Od 1950 r. prokuratura wydzielona była w odrębny pion organów państwowych z uwagi na pełnienie funkcji nadzoru ogólnego prokuratury, tj. funkcji alternatywnych do spełnianych przez sądownictwo, w szczególności sądownictwo administracyjne. Ta sytuacja miała ulec zmianie w wyniku poprawki grudniowej.

Poprawkę dotycząca prokuratury zaproponowano w grudniu w dość schematyczny sposób. Prokuratura została podporządkowana rządowi, czego logiczną konsekwencją było uregulowanie, że funkcje prokuratora generalnego pełni minister sprawiedliwości. Taki sposób usytuowania prokuratury niewatpliwie zbliżał rozwiązania ustrojowe do systemu opartego na zasadzie podziału władz. Prokuratura po poprawkach z grudnia 1989 r. mieściła się w tym podziale, albowiem stała się elementem władzy wykonawczej.

Ta zmiana pozycji prokuratury znalazła swoje odzwierciedlenie w art. 64 Konstytucji ${ }^{13}$. Przepis Konstytucji w wyniku tych zmian uzyskał jednakże wyraźnie eklektyczny charakter. Zmieniony art. 64 Konstytucji uzyskał następująca treść: „1. Prokuratura strzeże praworządności oraz czuwa nad ściganiem przestępstw. 2. Prokuratura podlega Ministrowi Sprawiedliwości, który sprawuje funkcje Prokuratora Generalnego. 3. Tryb powoływania i odwoływania

${ }^{11}$ Spór ten dał o sobie znać już w trakcie obrad Okragłego Stołu. Strona solidarnościowo-opozycyjna optowała wyraźnie za podporządkowaniem prokuratury ministrowi sprawiedliwości jako konsekwencji trójpodziału władz, ówczesna zaś strona koalicyjno-rządowa uważała, że problem powinien być rozważony w toku podejmowania w przyszłości reform ustrojowych państwa. Por. Porozumienia Okragłego Stołu, Wyd. NSZZ „Solidarność” Region Warmińsko-Mazurski 1989, s. 62 .

${ }^{12}$ Dz. U. 1989, Nr 19, poz. 101.

${ }^{13}$ Ustawa o zmianie Konstytucji PRL z 29 grudnia 1989 r., Dz. U. 1989, Nr 75, poz. 444. 
prokuratorów oraz zasady organizacji i postępowania organów prokuratury określa ustawa”. Artykuły 65 i 66 zostały skreślone.

Brzmienie tego przepisu było niewątpliwie wyrazem pewnego pośpiechu i braku głębszej debaty teoretycznej, a także pewnej niespójności wewnętrznej, i to z kilku względów:

1) pozostawiono przepisy dotyczące prokuratury, mimo że stała się ona elementem władzy wykonawczej, w dotychczasowym miejscu w Konstytucji;

2) wymieniono funkcję tylko jednego z ministrów w Konstytucji (ministra sprawiedliwości), podczas gdy inni nie są w niej wzmiankowani z nazwy;

3) pozostawiono funkcję prokuratury polegającej na strzeżeniu praworządności. Już sam fakt, że używa się w tym kontekście słowa „praworządność", podczas gdy wykreślono je z rozdziału Konstytucji o zasadach ustroju, może budzić wątpliwości. Jeśli jednak przyjaćc, że praworządność oznacza rządy prawa, a te sa jednym z istotnych elementów państwa prawa, to za politykę przestrzegania prawa odpowiada cały rząd, a nie tylko jeden z jego ministrów z tytułu sprawowania funkcji prokuratora generalnego.

Zaznaczyć jednak trzeba, że o tę funkcję prokuratury toczyły się od początku zmian w Konstytucji spory. Niektórzy autorzy podkreślali, że prokuratura, mimo iż jest elementem władzy wykonawczej, powinna pozostać organem chroniącym praworządnośćc ${ }^{14}$.

Niezależnie jednak od nieprecyzyjności tych sformułowań wynikających z nacisku chwili, sama koncepcja podporządkowania prokuratury rzadowi była koncepcją uzasadnioną. Nie można jej było uznać za sprzeczną z rozwiązaniami demokratycznymi i państwa prawa. Podkreślano to niejednokrotnie w literaturze przedmiotu, nawet przed 1989 r., że wydzielenie prokuratury prowadzi do sytuacji, w której minister sprawiedliwości ma zbyt mały wpływ na kształtowanie walki z przestępczością i ochronę praworządności.

Konsekwencja powierzenia ministrowi sprawiedliwości pełnienia funkcji prokuratora generalnego było utworzenie odpowiedniego departamentu prokuratury (zamiast odrębnej instytucji, jaką była Prokuratura Generalna), aby dopasować jej organizację do struktury wewnętrznej ministerstwa ${ }^{15}$.

Zmieniona Konstytucja nałożyła także obowiązek uchwalenia ustawy o prokuraturze, stanowiąc zarazem, że prokuratura działa na dotychczasowych zasadach do czasu uchwalenia nowej ustawy, nie dłużej jednak niż do 31 marca 1990 r. Termin zatem na opracowanie nowych rozwiązań ustawowych był niezwykle krótki. Jak się okazało, było to niemożliwe, zarówno ze względów politycznych, jak i merytorycznych, aby przygotować w tak krótkim terminie nową ustawę. Pozostała zatem droga dokonywania zmian w ustawie już istniejącej, pochodzącej z 1985 r. I niestety ten sposób regulacji trwa do dzisiaj, poprzez kolejne nowelizacje ustawy uchwalonej pięć lat przed rozpoczęciem procesu transformacji. To m.in. jest też dowodem na złożoność

${ }_{14}$ A. Murzynowski, Pozycja ustrojowa i zadania prokuratury-samodzielność czy powiazania $z$ administracja, w: Studia Konstytucyjne, t. 5: Organy ochrony prawa. Regulacja w nowej konstytucji, red. L. Garlicki, Warszawa 1989, s. 141-142.

15 Dz. U. 1990, Nr 20, poz. 121 (nowelizacja z 22 marca 1990 r. ustawy o prokuraturze z 1985 r.). 
materii $\mathrm{i}$ istnienie kontrowersji związanych $\mathrm{z}$ wyborem modelu ustrojowego prokuratury.

W znowelizowanej ustawie znalazły się regulacje, które wywoływały wiele wątpliwości, ponieważ nie były spójne z nowym usytuowaniem prokuratury jako elementu władzy wykonawczej.

Tytułem przykładu wskazywano na niektóre kompetencje prokuratora zawarte w art. 6 ustawy. Wyeksponowana została rola prokuratora polegajaca na przestrzeganiu praworządności, co znajdowało swoją podstawę w Konstytucji, która podkreślała tę rolę prokuratury. Rodziło to jednak pewne niekonsekwencje. W rezultacie bowiem Prokurator Generalny, już przecież jako organ władzy wykonawczej, uzyskał w świetle art. 6 ust. 1 ustawy uprawnienie, aby przed wystapieniem do TK o stwierdzenie zgodności aktu normatywnego naczelnego lub centralnego organu administracji państwowej mógł wystapić do rządu o zmianę aktu wydanego przez naczelny organ administracji. Była to sytuacja dość nietypowa w zakresie stosunków pomiędzy rządem a ministrami wchodzącymi w jego skład. Jeden z członków Rady Ministrów dysponował niezwykle silnymi środkami kontroli przestrzegania prawa w stosunku do innych członków rządu.

Tego typu regulacje były konsekwencjami dość mechanicznego wprowadzania zmian do ustawy opartej na zupełnie innej koncepcji ustrojowej prokuratury (niezależnego pionu). Zmiany na poziomie ustawowym dokonywane były równolegle z toczącymi się pracami konstytucyjnymi, co w rezultacie czyniło zarówno samą ustawę, jak i całą opartą na niej strukturę organów prokuratury coraz mniej koherentna.

Próba zdefiniowania roli ustrojowej prokuratury przewijała się, jak już zaznaczyłam, w trakcie całej debaty konstytucyjnej, która toczyła się w Polsce od 1989 r. do uchwalenia nowej konstytucji w 1997 r. Problem regulacji pozycji ustrojowej prokuratury i pozycji prokuratora powracał w toku prac kolejnych komisji konstytucyjnych. Pojawiały się głosy wskazujące na potrzebę wprowadzenia do nowej konstytucji przepisów dotyczących prokuratury. Nie uzyskały one jednak wsparcia większości w trakcie prac komisji konstytucyjnej. W rezultacie w Konstytucji z 1997 r. przepisy dotyczace prokuratury się nie znalazły. Podkreślić jednak należy, że takie stanowisko nie wynikało z braku woli politycznej czy braku determinacji kolejnych ministrów sprawiedliwości, jak czasami wskazywano w literaturze ${ }^{16}$. Było to rozwiązanie logiczne wynikajace z koncepcji podporządkowania prokuratury Radzie Ministrów. Wzięto pod uwagę krytyczne opinie, jakie do rozwiązania wprowadzonego w grudniu 1989 r. były wysuwane przez specjalistów prawa konstytucyjnego ${ }^{17}$, a także rozwiązania istniejące w innych krajach, w których przyjęto zbliżony model prokuratury, np. w Austrii czy w Niemczech. Niekonsekwencje zatem, które znalazły się tekście znowelizowanej konstytucji po dokonaniu poprawek grudniowych z 1989 r., zostały w tekście nowej Konstytucji z 1997 r. usunięte. Skoro funkcję prokuratora generalnego pełni jeden z ministrów - minister sprawiedliwości,

${ }^{16}$ H. Zięba-Załucka, Prawnoustrojowe problemy prokuratury RP, w: Trzecia władza, sqdy i trybunaty w Polsce, Wydawnictwo Uniwersytetu Gdańskiego, Gdańsk 2008, s. 237.

$17 \mathrm{~Np}$. opinia A. Gwiżdża przygotowana dla komisji ustawodawczej Sejmu. 
to dla regulacji prokuratury wystarczy forma ustawy. Niepotrzebne sa regulacje na poziomie konstytucji. Konstytucja zatem tworzyła podstawy do ujęcia prokuratury w ramach zasady podziału władz, sytuując ją w ramach władzy wykonawczej.

Taka podstawa konstytucyjna wymagała jak najszybszego uchwalenie nowej ustawy o prokuraturze, aby jednoznacznie w drodze ustawy określić szczegółowe zasady działania prokuratury w ramach koncepcji podziału władz oraz określić status prokuratorów i zakres (gwarancje) ich niezależności. Konieczne było w wyniku uchwalenia ustawy zamknięcie reformy, która rozpoczęła się w 1989 r. i nie została zakończona. Tak np. nie powołano instytucji sędziego śledczego, ta bowiem w tym systemie, do którego się odwoływano, istniała. System zatem zawierał ewidentne luki. Nowej ustawy jednak stale nie było.

Stąd pozostała droga nowelizacji starej ustawy. Była ona zmieniana wielokrotnie, zarówno przed uchwaleniem Konstytucji z 1997 r., jak i po jej uchwaleniu. Jedna z istotnych nowelizacji była zmiana ustawy dokonana w 1996 r. ${ }^{18}$, kiedy to zniesiono departament prokuratury w Ministerstwie Sprawiedliwości i powołano Prokuraturę Krajową z Prokuratorem Krajowym, który został zastępcą Prokuratora Generalnego - Ministra Sprawiedliwości. Ustawa wymienia go wręcz na pierwszym miejscu wśród zastępców Prokuratora Generalnego. Nowelizacja ta była wynikiem dążenia do doprowadzenia do zgodności struktury prokuratury ze strukturą sądów. Miało to wzmocnić pozycję prokuratora, ale zarazem w jakimś sensie ograniczyć polityczny charakter ministra sprawiedliwości w obrębie prokuratury. Powołanie Prokuratury Krajowej wywołało jednak wiele kontrowersji. Mimo że była ona formalnie strukturą wewnętrzną Ministerstwa, to jednak zaczęła się rozrastać i nie mieścić się organizacyjnie w jego ramach. W tym czasie podejmowano kolejne próby przygotowania nowej całościowej ustawy o prokuraturze wpisanej w system podziału władz, w którym to systemie prokuratura jest elementem władzy wykonawczej. Niestety kolejne projekty nie uzyskiwały akceptacji i dlatego nadal nowelizowano istniejaccą ustawę.

Kolejnej, fundamentalnej zmiany ustawy z 1985 r. dokonano w 2009 r. Wówczas to ustawą z 9 października 2009 r. ${ }^{19}$ dokonano rozdzielenia funkcji Prokuratora Generalnego i Ministra Sprawiedliwości. Zlikwidowano Prokuraturę Krajowa. Utworzono Prokuraturę Generalną jako centralną jednostkę organizacyjna prokuratury. Z nazwy zatem powrócono do sytuacji sprzed nowelizacji 1989 r. Status prawny prokuratury pozostał natomiast znacznie bardziej złożony. Mimo rozdziału funkcji zachowano szereg przepisów wiążących prokuraturę z władzą wykonawczą i poddających ją swoistej kontroli Prezesa Rady Ministrów. Tak np. Minister Sprawiedliwości tworzy i znosi prokuratury apelacyjne, okręgowe i rejonowe, ustala ich siedziby i obszary właściwości (art. 17, pkt 13, 14, 15 znowelizowanej ustawy). Minister Sprawiedliwości usta-

18 Ustawa z 10 maja 1996 r. o zmianie ustawy o prokuraturze, o Sądzie Najwyższym, o Trybunale Konstytucyjnym oraz ustawy - Prawo o ustroju sądów powszechnych i ustawy - Prawo o adwokaturze, Dz. U. Nr 77, poz. 367.

19 Dz. U. 2009, Nr 178, poz. 1375. 
la w drodze rozporządzenia, po zasięgnięciu opinii Prokuratora Generalnego, regulamin wewnętrznego urzędowania powszechnych jednostek organizacyjnych prokuratury (art. 18.1).

Także Prezes Rady Ministrów ma określone uprawnienia względem Prokuratora Generalnego, które osadzone są w art. 146 ust. 4 pkt 7 w powiązaniu z art. 148 ust. 4) Konstytucji RP, mówiącym o tym, że Rada Ministrów zapewnia bezpieczeństwo wewnętrzne państwa oraz porządek publiczny, a Prezes Rady Ministrów zapewnia wykonywanie polityki Rady Ministrów. W związku z tym Prokurator Generalny przedstawia Prezesowi Rady Ministrów sprawozdanie z rocznej działalności prokuratury. Prezes Rady Ministrów przyjmuje albo odrzuca sprawozdanie. W przypadku odrzucenia sprawozdania premier może wystapić do Sejmu z wnioskiem o odwołanie Prokuratora Generalnego przed upływem kadencji. Przed złożeniem takiego wniosku zasięga opinii Krajowej Rady Prokuratorów. Prezes Rady Ministrów może też domagać się od Prokuratora Generalnego w każdym czasie przedstawienia informacji na określony temat związany ze strzeżeniem praworządności oraz czuwaniem nad ściganiem przestępstw ${ }^{20}$.

Wydaje się jednak, że niezależnie od tych uprawnień władzy wykonawczej w stosunku do Prokuratora Generalnego ta nowelizacja oznaczała krok w kierunku wydzielenia prokuratury z władzy wykonawczej i, można zakładać, uczynienia jej organem niezależnym ${ }^{21}$. Świadczyć o tym może także fakt powoływania Prokuratora Generalnego. Sposób jego powoływania zbliżony jest do powoływania prezesa Trybunału Konstytucyjnego czy prezesa Sądu Najwyższego. Prokuratora Generalnego powołuje bowiem Prezydent Rzeczypospolitej Polskiej spośród kandydatów zgłoszonych przez Krajową Radę Sądownictwa i Krajową Radę Prokuratury, które to Rady zgłaszają po jednym kandydacie nie później niż na cztery miesiace przed upływem kadencji Prokuratora Generalnego albo w ciagu dwóch miesięcy od jej wygaśnięcia.

Można jednak wyrazić zasadnicze waţpliwości, czy usytuowanie prokuratury jako organu niezależnego od rządu posiada umocowanie w świetle przepisów Konstytucji z 1997 r. Skoro urząd Prokuratora Generalnego przestaje być powiązany z funkcją ministra - członka rządu, to wydaje się, że wymaga on zakotwiczenia konstytucyjnego ${ }^{22}$. Podtrzymuję opinię, że przy istnieniu więzi personalnej pomiędzy Ministrem Sprawiedliwości a Prokuratorem Generalnym takiej potrzeby nie było, albowiem był to jeden z ministrów rządu. Obecnie jest to odrębny organ państwowy wyłamujący się w jakimś sensie $\mathrm{z}$ istniejącego podziału władz, niestanowiący jednoznacznie elementu władzy wykonawczej, mimo pewnych uprawnień, jakie w stosunku do niego posiada Prezes Rady Ministrów czy Minister Sprawiedliwości.

20 Art 10e znowelizowanej ustawy o prokuraturze, Dz. U. 2009, Nr 178, poz. 1375.

21 A. Herzog, Niezależność prokuratury - mit czy nadzieja?, „Prokuratura i Prawo” 2009, nr 1.

22 A. Stankowski, Propozycja unormowań prokuratury w Konstytucji RP, „Prokuratura i Prawo" 2009 , nr 10. 
$\mathrm{Na}$ początku transformacji zwracano uwagę na to, że we współczesnych państwach istniejacy trójpodział władzy bywa przełamywany. Pojawiają się bowiem instytucje kontrolne, pełniące swoje funkcje w sposób stosunkowo niezależny od innych organów, np. ombudsman. W warunkach polskich - Najwyższa Izba Kontroli (mimo jej podległości Sejmowi). Czy wśród tych organów wyłamujących się z klasycznego trójpodziału władz ma znajdować się prokuratura? To pytanie wówczas postawiono ${ }^{23}$.

Po nowelizacji ustawy z 2009 r. to pytanie nabiera większej aktualności. Ostateczna odpowiedź nie została udzielona. Konstytucja w zasadzie takiej podstawy nie stanowi. Ustawa zaś jest tylko cząstkowa. Jest kolejną nowelizacją ustawy pochodzącej z dalekiego okresu przed transformacją (1985 r.). Brak jest w tym świetle jednoznacznej zwartej koncepcji. Nie ma tutaj pełnej koherencji pomiędzy rozwiązaniami Konstytucji, milczącymi, albowiem wychodzącymi z założenia, że funkcję prokuratora generalnego pełni jeden z ministrów, a ustawą.

Obecnie jednak dysponujemy znacznie lepszymi instrumentami zarówno europejskimi, jak i uniwersalnymi dotyczacymi usytuowania i organizacji prokuratury. Ze względu na to, że w zasadzie wszystkie państwa Europy Środkowej i Wschodniej borykaja się z tym problemem, uchwalonych zostało w tym czasie szereg dokumentów, które mają stanowić odniesienia do poszukiwania rozwiązań krajowych w kwestii prokuratury, zgodnych z tzw. standardami europejskimi ${ }^{24}$.

Rozwiąania przyjęte przez państwa Rady Europy w zakresie usytuowania i organizacji prokuratury, jak już zaznaczyłam, są różnorodne. Poszukiwania wielu państw Europy Środkowej i Wschodniej, w odróżnieniu od tzw. tradycyjnych demokracji, koncentrują się raczej wokół usytuowania prokuratury jako organu niezależnego, niepowiązanego z władzą wykonawcza.

Podkreślić jednak należy, że niezależnie od sposobu usytuowania prokuratury w systemie organów państwowych, co wydaje się kwestią ważna, ale jednak nie pierwszoplanowa, konieczny jest pewien katalog zasad, gwarancji, które mają zapewnić bezstronność prokuratora przy podejmowaniu decyzji ${ }^{25}$, ale także i określić zasady jego odpowiedzialności. I są one tak samo ważne zarówno w przypadku podporządkowania prokuratora rządowi (aby uwolnić go od nacisków politycznych), jak i w przypadku niezależności organów prokuratury (aby uwolnić go od nacisków wewnątrz prokuratury).

\footnotetext{
${ }^{23}$ H. Suchocka, L. Kański, op. cit., s. 17.

${ }^{24}$ Można tu wymienić m.in. następujące dokumenty: - Recommendation Rec(2000)19 of the Committee of Minister of the Council of Europe on the Role of Public Prosecution in the Criminal Justice System; - The 1990 United Nations Guidelines on the Role of Prosecutors; - The 1999 IAP (International Association of Prosecutors) Standards of Professional Responsibility and Statement of the Essential Duties and Rights of Prosecutors; - The Bordeaux Declaration of the Consultative Council of European Judges (CCJE) and the Consultative Council of European Prosecutors (CCPE) on „Judges and Prosecutors in a Democratic Society”; - The European Guidelines on Ethics and Conduct for Public Prosecutors (Council of Europe, „Budapest Guidelines”, 2005); European Standards as regards the Independence of the Judicial System, part II - the prosecution service (CDL-AD(2010)040).

${ }^{25}$ Por. w tym zakresie także: A. Gaberle, $O$ nowy kształt prokuratury $w$ Polsce, „Państwo i Prawo" 2007, z. 8, s. 6-7.
} 
Stąd też w raporcie Komisji Weneckiej stanowiącym swoiste wytyczne (guide-lines) w zakresie zasad organizacji prokuratury wskazuje się na następujace gwarancje:

1. Gwarancje wewnętrznej i zewnętrznej niezależności prokuratora, tj. takie instrumenty, które powstrzymują rząd (ministra) od ingerencji w poszczególne sprawy, ale także zakazują wpływania przez „innych” w obrębie prokuratury (nawet gdy jest ona wydzielona) na decyzje prokuratora.

Te dwie generalne zasady powiązane sa z zasadą hierarchicznego podporządkowania, która uznawana jest za jedną z zasad organizacyjnych prokuratury. Komisja Wenecka w swoim raporcie podkreśla, że nawet w sytuacji kiedy prokurator jest częścią systemu sądowego, nie jest on sądem, i ten fakt determinuje zakres jego niezależności. W przypadku sądu niezależność i niezawisłość stanowią kamień węgielny państwa prawa. Natomiast niezależność prokuratora nie jest tak kategoryczna ze swojej istoty i dopuszcza wydawanie instrukcji pod wyraźnie określonymi warunkami. Nawet w przypadku zorganizowania prokuratury na zasadzie niezależności (wydzielenia od władzy wykonawczej) zasada hierarchiczności jest stosowana. Niezbędne sa jednak określone gwarancje przysługujące prokuratorowi, w stosunku do którego takie instrukcje sa kierowane ${ }^{26}$.

Kwestię reguł dotyczących wydawania instrukcji reguluje m.in. Rekomendacja Komitetu Ministrów Rady Europy z 2000 r. ${ }^{27}$ Stwierdza ona, że „każdy prokurator ma prawo domagać się, aby kierowane do niego instrukcje były na piśmie. Jeśli uważa on, że instrukcja jest niezgodna z prawem lub przeciwna jego przekonaniu, musi mieć możliwość oceny tego w ramach odpowiedniej wewnętrznej procedury, która może prowadzić do zastapienia go inną osobą”.

Komisja Wenecka w swoim raporcie, który przyjęła 10 lat później aniżeli rekomendacje Komitetu Ministrów, stwierdza, że zawarte tam gwarancje nie są wystarczające do zapewnienia niezależności działania prokuratora. Możliwość odsunięcia prokuratora od sprawy, gdy nie zgadza się on z instrukcja, jest zbyt słabą gwarancją. Nie można bowiem wykluczyć celowego wydania takiej instrukcji, aby właśnie odsunaćc prokuratora od sprawy i przekazać jac innemu. Gwarancja polegajaca na niewywieraniu nacisku na prokuratora w obrębie prokuratury wymaga, aby taka instrukcja, zwłaszcza jeśli zarzuca się jej niezgodność z prawem, została poddana ocenie przez niezależny organ (np. Radę Prokuratorów).

2. Sposób powoływania prokuratora generalnego

Istotny dla zapewnienia pozycji prokuratora i jego bezstronności politycznej jest sposób jego powoływania. I tutaj podobnie jak w wielu innych kwestiach związanych z organizacją prokuratury nie można w świetle standardów europejskich sformułować jednej kategorycznej zasady dotyczacej sposobu powoływania prokuratora generalnego, a zwłaszcza tego, czy ma go powoływać

26 (CDL-AD(2010)040 p. 28).

27 Point 10 of Recommendation 2000 (19). 
prezydent czy parlament w sytuacji, kiedy nie jest on podporządkowany rządowi. Problem jest w różny sposób rozwiązywany w poszczególnych państwach. Ważną rolę w procesie powoływania, na co wskazuje Komisja Wenecka, odgrywa stosowanie swoistej zasady kooperacji różnych organów w tym procesie, co pozwalałoby uniknaćc jednostronnej politycznej nominacji. Proces nominacji kandydatów musi być w każdej sytuacji wyraźnie określony ustawowo.

Tam gdzie istnieje Rada Prokuratorów, może ona wskazywać kandydata na prokuratora, a nominacji może dokonywać prezydent, tak np. jak to jest obecnie w systemie polskim po zmianie z 2009 r. Pewne zastrzeżenia są wyrażane w opinii Komisji Europejskiej co do trybu powoływania prokuratora przez parlament, z obawy przed nadmierna polityzacja tego procesu ${ }^{28}$. Prokurator generalny powinien być powoływany na stosunkowo długi okres bez możliwości ponownej nominacji na to stanowisko.

Podstawy odwołania prokuratora generalnego przed terminem muszą być przewidziane wyraźnie ustawą.

\section{Zasada odpowiedzialności}

Usytuowanie prokuratora jako organu niezależnego nie może go czynić całkowicie wyłączonym od odpowiedzialności. Jego działalność powinna być poddana ocenie. Jako jeden z możliwych przykładów takiej odpowiedzialności wskazuje się składanie rocznych raportów przez prokuratora rządowi lub parlamentowi. Podkreśla się, że w takim raporcie, tak dalece jak to jest możliwe, powinno być wykazane w sposób transparentny, jak generalne instrukcje przekazane przez rząd zostały zrealizowane. Zgodnie bowiem z opinią Komisji Weneckiej rząd może stosować określona politykę - wskazywać na priorytety ścigania pewnych przestępstw i nie może to być traktowane jako ingerencja w niezależność prokuratury, jeśli dotyczy zasadniczych linii politycznych ${ }^{29}$.

\section{Rada Prokuratorów}

Trudno byłoby wskazać na jeden model takiej rady istniejacy we wszystkich państwach Rady Europy. Co więcej, jak podkreśla się w raportach Komisji Weneckiej, w istniejacym stanie prawnym państw Rady Europy trudno byłoby nawet zakładać obowiązek powołania takiej rady jako powszechnie wiążacy standard europejski. Jest bowiem wiele państw europejskich, „tradycyjnych demokracji”, w których takie rady nie istnieja, i nie można tej sytuacji uznać za sprzeczną ze standardami europejskimi.

Faktem natomiast jest, że w zasadzie we wszystkich tzw. nowych demokracjach takie rady zostały utworzone. Skład ich jest zróżnicowany. Z reguły w ich skład wchodzą prokuratorzy różnych szczebli, ale także niejednokrotnie przedstawiciele innych zawodów prawniczych, adwokaci, profesorowie prawa. Niejednokrotnie są to rady wspólne dla sędziów i prokuratorów, czasami od-

${ }^{28}$ (CDL-AD(2010)040).

29 ,[T] $[$ he making of prosecution policy (for example giving priority to certain types of cases, time limits, closer cooperation with other agencies, etc.) seems to be an issue where the Legislature and the Ministry of Justice or Government can properly have a decisive role" (CDL$\mathrm{AD}(2010) 040)$, s. 43. 
rębne. W sytuacji jednak, w której istnieje wspólna rada dla sędziów i prokuratorów, obie grupy powinny głosować odrębnie w kwestiach dotyczących nominacji i odpowiedzialności dyscyplinarnej sędziów i prokuratorów. Rozwiązaniem optymalnym byłoby, aby taka wspólna rada podzielona była na dwie izby, jak to ma miejsce np. we Francji ${ }^{30}$.

\section{Zakres władzy prokuratora}

Ponieważ szereg państw przechodzących transformację i poszukujących obecnie nowych rozwiązań dla usytuowania prokuratury ma odniesienia do poprzedniego systemu silnej prokuratury radzieckiej, rekomendacje europejskie przestrzegaja przed zbytnim rozszerzaniem władzy prokuratora, charakterystycznym dla tamtego systemu. Takie tendencje bowiem w niektórych państwach istnieja, czego przykładem sa przedkładane do opinii Komisji Weneckiej projekty ustaw. Zgodnie ze wskazaniami Rady Europy, władza prokuratora z istoty swojej powinna koncentrować się wokół postępowań karnych ${ }^{31}$. Szereg funkcji, np. związanych z ochroną praw człowieka, które w poprzednim systemie przypisywane były prokuratorowi (i takie rozwiązania w niektórych państwach znajdują się do dziś), zostało przejętych $\mathrm{w}$ nowych warunkach w wielu państwach przez inne instytucje, w tym rzecznika praw obywatelskich, i nie powinny być przypisywane prokuratorze.

Szczególne wątpliwości wywołuje możliwość stosowania nadzwyczajnych środków prawnych przez prokuratora w stosunku do ostatecznych orzeczeń sądowych. Odwołać się tu należy do orzeczenia Europejskiego Trybunału Praw Człowieka w sprawie Brumarescu v Romania (28342/95 z 28 października 1999 r.), w którym Trybunał stwierdził, że władza prokuratora generalnego w odniesieniu do orzeczenia cywilnego, w którym państwo rumuńskie nie było strona, narusza art. 6.1 Konwencji o ochronie praw człowieka i podstawowych wolności. Podważa także jedną z zasad państwa prawa, jaka jest zasada pewności prawnej, która oznacza m.in., że ostateczne orzeczenie sądu nie powinno być podważane.

Wydaje się zatem oczywiste, że dwadzieścia pięć lat, które upłynęło od początku transformacji, i prawie trzydzieści lat od uchwalenia ustawy o prokuraturze PRL stale obowiązującej w polskim systemie, wymagają bezwzględnie nowej ustawy o prokuraturze, będącej w zgodzie ze standardami europejskimi, a zarazem wykorzystującymi pozytywne doświadczenia minionych lat. Aby

${ }^{30}$ Odrębne rady prokuratorów istnieją np. w Bośni i Hercegowinie, Mołdawii (CDL(2008)055), Czarnogórze (CDL(2008)023), Serbii (CDL(2009)103), Macedonii” (CDL(2007)023). Francja, Włochy, Turcja (CDL(2010)125) mają rady sądownicze, które posiadają kompetencje także w sprawach prokuratorów, ale z odrębną izbą prokuratorską we Francji (CDL-AD(2010)040), s. 66.

${ }^{31}$ Temu zagadnieniu poświęcona była specjalna konferencja prokuratorów na temat „The role of the prosecutor services as regards non-criminal matters in different legal systems: different legal traditions and practices to defend common standards and goals - the constitutional perspective”, Petersburg, 2-3 lipca 2008 r. Stanowisko Rady Europy w tej kwestii wyrażone zostało m.in. w Rekomendacji 1604 (2003) Zgromadzenia Parlamentarnego RE, stwierdzajaccej, że: „the power and responsibilities of prosecutors are limited to the prosecution of criminal offences and a general role in defending public interest through the criminal-justice system, with separate, appropriately located and effective bodies established to discharge any other function". 
jednak do tego doszło, konieczne jest znalezienie konsensusu wokół modelu prokuratury i jej usytuowania w systemie organów państwowych i w konsekwencji udzielenia odpowiedzi na pytanie co do potrzeby jej konstytucjonalizacji. Inaczej nowa ustawa będzie zawieszona w próżni i poddawana stale kolejnym cząstkowym nowelizacjom przez kolejne ekipy polityczne.

\author{
dr Hanna Suchocka \\ Profesor Uniwersytetu im. Adama Mickiewicza w Poznaniu
}

\title{
SEARCHING FOR A NEW MODEL OF THE PUBLIC PROSECUTION REGIME (IN LIGHT OF THE WORK OF THE EUROPEAN COMMISSION FOR DEMOCRACY THROUGH LAW)
}

\section{Sum mary}

Looking back at the twenty five years that have passed after the transformation processes started in the countries of Eastern and Central Europe we may say that each of these countries had to cope with the same major challenge in the course of the reform of the system of state organs: the place of the prosecution regime

Consequently, each embarked on finding solutions which, by breaking away with the principle of the unity of power, would allow to arrive at the most effective model for situating the prosecution within the system of separation and balance of powers. As emphasised by the Venice Commission, there is no uniform model of the prosecution regime in the European system. Lawmakers may therefore choose from among different scenarios which all meet so-called European standards. Consequently, it may be claimed that none of the existing solutions, be it a model subordinating the prosecution to the parliament, or to the government, may be classified as contrary to democratic norms. No doubt, further, that in individual states efforts to find a proper place for the prosecution were determined by their legal traditions.

Poland for that matter found itself in a relatively privileged position when compared with other states as it already had its own tradition. Thus, in an attempt to find the best possible option in the circumstances of 1989 with respect to the regime structure it was decided to rely on the solutions existing prior to the Constitution of 1952, and to rely on the solutions from before 1950 with respect to the prosecution.

Following the amendments to the Constitution in 1989, the prosecution became subordinate to government. The logical consequence of this decision was a regulation that the function of the Attorney General (General Prosecutor) is performed by the Minister of Justice.

Irrespective of the absence of precision in this expeditious formulation, the very idea of the concept of government-subordinated prosecution was justified and could not be considered contradictory to the democratic solution and the rule of law. There was no time, however, to draft and adopt a new act on the prosecution. Consequently, it was decided to regulate the prosecution by amending the existing law of 1985 . Unfortunately, this other option of regulating the prosecution has continued till the present, with the result that the prosecution today is governed by the provisions of an act adopted five years before the process of transformation even began.

The act underwent multiplied amendments, both before the adoption of the Constitution of 1997 as well as thereafter. One of the important changes was the amendment of 1996, liquidating the prosecution department at the Ministry of Justice and creating the National Public Prosecutor's Office and the office of the Public Prosecutor who became at the same time deputy General Prosecutor (Attorney General) - the Minister of Justice.

Another substantial amendment to the act of 1985 was adopted in 2009 when the functions of the Prosecutor General and the Ministry of Justice had been separated. The National Public Prosecutor's Office was liquidated and replaced with the General Prosecutor's Office taking the role of the central organisational unit of the prosecution. This amendment allowed to secure a number of executive power competences in relation to the prosecution. Despite that, it seems 
that a step has been made towards singling out the prosecution from the executive power in order to, as may be assumed, turn it into an independent body.

Certain doubts, however, arise regarding the validity of the place of the prosecution as a body independent of the government in light of the provisions of the Constitution of 1997: since the office of the General Prosecutor is no longer to be tied to the function of the Minister of Justice (i.e. a member of government), it seems that such change must be anchored in the Constitution. It also needs to be emphasised that regardless of the place the prosecution occupies in the state bodies regime, which of course is also of importance, what is really necessary is a catalogue of principles and guarantees that will not only ensure impartiality of the prosecutor in decisions making, but will also determine his liability. These guarantees are equally essential in the case of the government-subordinated prosecutor (to free him from political pressure) as well as in the case of independent prosecution (to eliminate pressures within the prosecution itself).

It is rather obvious that twenty five years after the beginning of transformations and almost thirty years since the adoption of the still binding and applicable Act on Prosecution in the Polish People's Republic, a new act on the prosecution must be drafted in line with the European standards, which will also account at the same time, for the positive experiences of the past decades. 
Copyright of Journal of Law, Economics and Sociology is the property of Faculty of Law and Administration of Adam Mickiewicz University in Poznan and its content may not be copied or emailed to multiple sites or posted to a listserv without the copyright holder's express written permission. However, users may print, download, or email articles for individual use.

Właścicielem praw autorskich do „Ruchu Prawniczego, Ekonomicznego i Socjologicznego” jest Wydział Prawa i Administracji Uniwersytetu im. Adama Mickiewicza w Poznaniu. Zawartość czasopisma nie może być kopiowana, przesyłana do innych stron internetowych bądź zamieszczana na blogach bez pisemnej zgody wydawcy. Niemniej artykuły można drukować, kopiować lub przesyłać w formie elektronicznej na własny użytek. 